\title{
Urethral leiomyoma: a rare case of voiding difficulty
}

\author{
Soumya Cicilet, ${ }^{1}$ Thara Joseph, ${ }^{2}$ Farha Furruqh ${ }^{2}$ Asthik Biswas ${ }^{2}$
}

${ }^{1}$ Department of

Radiodiagnosis, St John's Medical College Hospital, Bangalore, Karnataka, India ${ }^{2}$ Department of Radiology, St John's Medical College Hospital, Bangalore, Karnataka, India

\section{Correspondence to}

Dr Asthik Biswas, asthikbiswas@gmail.com

Accepted 11 October 2016

CrossMark

To cite: Cicilet $S$, Joseph $T$, Furrugh $\mathrm{F}$, et al. BMJ Case Rep Published online: [please include Day Month Year] doi:10.1136/bcr-2016216728

\section{DESCRIPTION}

A woman aged 28 years presented with a history of voiding difficulty with straining on micturition for 2 months. She was completely asymptomatic and had no symptoms of voiding difficulty prior to this. On physical examination, she was found to have a firm tender mass measuring $2.5 \times 2 \mathrm{~cm}$, involving the posterior periurethral region. The urethral orifice could not be separately identified. Uroflowmetry was performed and was within the normal limit. Transperineal ultrasound revealed a well-defined homogeneously hypoechoic solid lesion anterior to the vagina. The posterior urethral wall could not be separately delineated from the lesion. On colour Doppler interrogation, the lesion showed significant internal vascularity (figure 1). There was no significant postvoid residue. MRI was performed for further characterisation of the lesion and its relation to adjacent structures. Axial, coronal and sagittal T2-weighted, short tau inversion recovery (STIR) and precontrast and postcontrast T1-weighted images were acquired. A well-defined focal lesion measuring $2.8 \times 2.5 \times 2.3 \mathrm{~cm}$ was noted below the level of pubic symphysis arising from the posterior wall of the distal urethra displacing the urethral meatus anteriorly. This lesion was anterior to the vagina with preserved intervening fat planes. The lesion showed intermediate signal intensity and was isointense to muscle on T1-weighted images (figure 2). It was hyperintense on T2 and STIR images when compared with muscle (figure 3). On postcontrast images, homogeneous enhancement was noted (figure 4). In view of the aforementioned imaging findings, a diagnosis of urethral leiomyoma was made. As the lesion had very well-defined noninfiltrative margins, a malignant aetiology was considered unlikely. The patient was posted for excision of leiomyoma. Intraoperatively, the mass was seen arising from the posterolateral wall of the distal urethra. The mass was excised and the specimen was sent for histopathological examination (HPE). HPE showed spindle-shaped cells arranged in whorls and fascicles consistent with leiomyoma (figure 5). The patient had an uneventful postoperative period. On follow-up, she had no symptoms of straining on micturition and had no significant postvoid residue on transabdominal sonography.

Leiomyomas are benign tumours arising from smooth muscle usually involving the genitourinary tract but may arise in any anatomic site. ${ }^{1}$ Among extrauterine leiomyomas, urethral leiomyomas are rare. ${ }^{2}$ The most useful imaging modalities for characterisation of such lesions are ultrasonography and MRI. ${ }^{13}$ In the genitourinary tract, urethra is a relatively rare location for leiomyoma. Approximately 120 cases of leiomyoma in female urethra have been reported in the literature so far. ${ }^{1}$ They occur in women of reproductive age group and show relation to hormonal status that is indicated by their increase in size during pregnancy and regression in the postpartum period. ${ }^{4}$ Rarely, these tumours occur in men and postmenopausal women. ${ }^{5}$ Most patients with urethral leiomyoma present with periurethral mass, haematuria, straining on micturition, dyspareunia and recurrent urinary tract infections. ${ }^{6}$ These tumours most commonly arise from the posterior wall of the proximal urethra. ${ }^{78}$ However, the lesion in our patient was noted arising from the posterior wall of the distal urethra.

On sonography, leiomyomas are solid, homogeneous, smooth-walled hypoechoic lesions with a typical whorled appearance which on colour Doppler sonography show internal vascularity. ${ }^{9}$ The primary role of USG is to determine whether the lesion is solid or cystic as this narrows down the differential diagnosis. MRI serves as a problem solving tool. It helps in the precise localisation of the mass and also to assess infiltration of surrounding structures. ${ }^{1}$ On MRI, leiomyomas show intermediate signal intensity on T1-weighted images, low to intermediate signal intensity on T2-weighted images and homogeneous postcontrast enhancement. ${ }^{10}$ The lesion in our patient showed similar signal intensity, except that on T2-weighted images, hyperintense signal was noted.

Differential diagnosis of a distal urethral mass in females includes malignant neoplasm of distal urethra, haemangioma, nerve sheath tumour, caruncle, urethral diverticulum and Skene duct cyst. Malignant neoplasms are more common in postmenopausal age group, usually have infiltrative ill-defined margins and show heterogeneous enhancement on contrast MRI. ${ }^{11}$ Haemangiomas and nerve sheath tumours show very high signal on T2-weighted images. Caruncles also show high

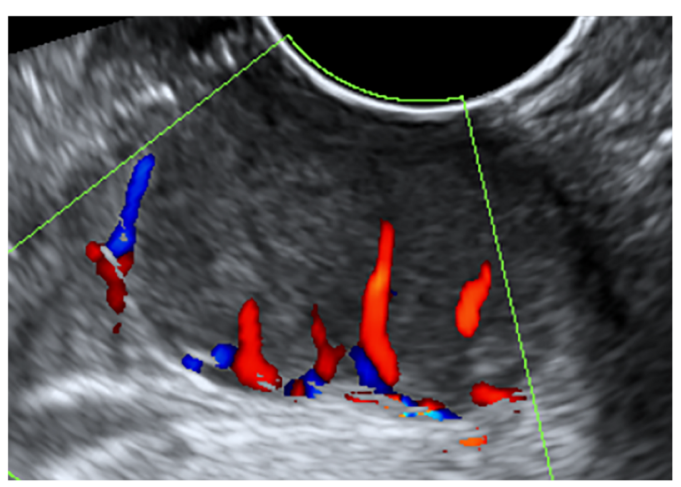

Figure 1 USG image showing a well-defined solid hypoechoic focal lesion showing Doppler flow signals within. 
Figure 2 Axial T1 and short tau inversion recovery (STIR) images showing a T1 isointense, STIR hyperintense focal lesion in the distal urethra.

Figure 3 Sagittal T2 and postcontrast $\mathrm{T} 1$ fat sat images showing a T2 mildly hyperintense distal urethral focal lesion with homogeneous contrast enhancement.

Figure 4 Coronal short tau inversion recovery (STIR) and postcontrast fat sat T1 images showing STIR hyperintense distal urethral focal lesion showing homogeneous contrast enhancement. STIR, short tau inversion recovery.
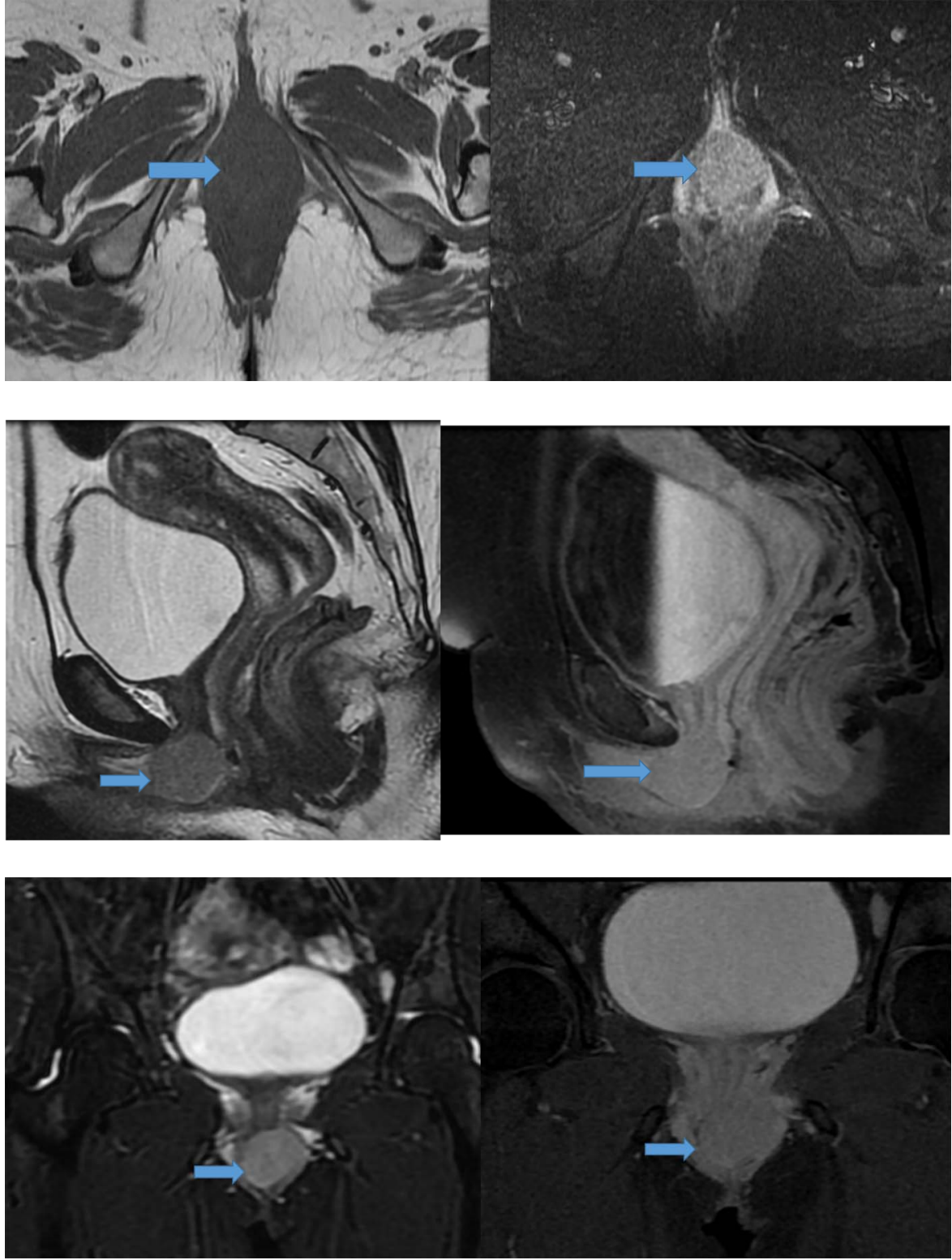

signal on T2-weighted images and are seen in postmenopausal patients. ${ }^{10}$ Urethral diverticulae and Skene gland cysts show fluid signal intensity on MRI with no enhancement. Complicated cysts and diverticulae can show variable signal intensity on MRI with variable enhancement. ${ }^{11}$

\section{Learning points}

- Urethral lesions are a rare cause of voiding difficulty. Of these, diverticulae and caruncles are the most common.

- Leiomyoma should be considered in the differential diagnosis of a urethral lesion in women of reproductive age group. The finding of a well-defined solid, homogenously enhancing mass should raise the possibility of the same. An infiltrative lesion should raise the possibility of a malignant neoplasm.

- Ultrasound and MRI are invaluable tools in characterising focal lesions of the female urethra.

- On histopathology, leiomyomas typically show spindle-shaped cells arranged in whorls and fascicles. 
Contributors SC wrote up the manuscript and performed the literature review. TJ and $A B$ contributed to the literature review, editing of the images, details of patient history, treatment and follow-up. FF supplied the images and reviewed the final manuscript. The guarantors for the overall content are $\mathrm{SC}$ and $\mathrm{AB}$.

Competing interests None declared.

Patient consent Obtained.

Provenance and peer review Not commissioned; externally peer reviewed.

\section{REFERENCES}

1 Fasih N, Prasad Shanbhogue AK, Macdonald DB, et al. Leiomyomas beyond the uterus: unusual locations, rare manifestations. Radiogr Rev Publ Radiol Soc N Am Inc 2008;28:1931-48.

2 Verma R, Mehra S, Garga UC, et al. Imaging diagnosis of urethral leiomyoma, usual tumour at an unusual location. J Clin Diagn Res 2014;8:RD04-6.

3 Goldman HB, McAchran SE, MacLennan GT. Leiomyoma of the urethra and bladder. J Urol 2007;177:1890.
4 Ozel B, Ballard C. Urethral and paraurethral leiomyomas in the female patient. Int Urogynecol J Pelvic Floor Dysfunct 2006;17:93-5.

5 Saad AG, Kaouk JH, Kaspar HG, et al. Leiomyoma of the urethra: report of 3 cases of a rare entity. Int J Surg Pathol 2003:11:123-6.

6 Cheng C, Mac-Moune Lai F, Chan PS. Leiomyoma of the female urethra: a case report and review. J Urol 1992:148:1526-7.

7 Leidinger RJ, Das S. Leiomyoma of the female urethra. A report of two cases. J Reprod Med 1995;40:229-31.

8 Lee MC, Lee SD, Kuo HT, et al. Obstructive leiomyoma of the female urethra: report of a case. J Urol 1995;153:420-1.

9 Ryu J, Kim B. MR imaging of the male and female urethra. Radiogr Rev Publ Radiol Soc N Am Inc 2001;21:1169-85.

10 Chaudhari VV, Patel MK, Douek M, et al. MR imaging and US of female urethral and periurethral disease. Radiogr Rev Publ Radiol Soc N Am Inc 2010;30: 1857-74.

11 Del Gaizo A, Silva AC, Lam-Himlin DM, et al. Magnetic resonance imaging of solid urethral and peri-urethral lesions. Insights Imaging 2013;4:461-9.

Copyright 2016 BMJ Publishing Group. All rights reserved. For permission to reuse any of this content visit http://group.bmj.com/group/rights-licensing/permissions.

BMJ Case Report Fellows may re-use this article for personal use and teaching without any further permission.

Become a Fellow of BMJ Case Reports today and you can:

- Submit as many cases as you like

- Enjoy fast sympathetic peer review and rapid publication of accepted articles

- Access all the published articles

- Re-use any of the published material for personal use and teaching without further permission

For information on Institutional Fellowships contact consortiasales@bmjgroup.com

Visit casereports.bmj.com for more articles like this and to become a Fellow 